\title{
Molecular detection of serotype groups of Listeria monocytogenes isolated from gallbladder of cattle and sheep in Iraq
}

\author{
Hamza Jawad Al-Ali' ${ }^{1}$, Mohsen Abd Al-Rodhan², Samer Abdulsahib Al-Hilali ${ }^{3}$, Alaa Hani Al-Charrakh4,
} Ali Muhsin Al-Mohana ${ }^{3}$ and Zainab Jaber Hadi

\begin{abstract}
1. Najaf Veterinary Hospital, Najaf Province, Iraq; 2. Department of Clinical and Laboratory Science, College of Pharmacy, University of Al-Qadisiyah, Diwaniyah, Iraq; 3. Department of Microbiology, College of Medicine, University of Kufa, Kufa, Iraq; 4. Department of Microbiology, College of Medicine, Babylon University, Hillah, Babylon Governorate, Iraq.

Corresponding author: Alaa Hani Al-Charrakh, e-mail: ahani67@gmail.com

Co-authors: HJA: hamzaalali@yahoo.com, MAA: moh.alrodhan@gmail.com, SAA: alhilali.samer@gmail.com, AMA: alialmohana@yahoo.com, ZJH: zainabj.hadi@uokufa.edu.iq

Received: 03-11-2017, Accepted: 27-02-2018, Published online: 07-04-2018
\end{abstract}

doi: 10.14202/vetworld.2018.431-436 How to cite this article: Al-Ali HJ, Al-Rodhan MA, Al-Hilali SA, Al-Charrakh AH, Al-Mohana AM, Hadi ZJ (2018) Molecular detection of serotype groups of Listeria monocytogenes isolated from gallbladder of cattle and sheep in Iraq, Veterinary World, 11(4): 431-436.

\begin{abstract}
Aim: This study was designed to investigate the occurrence of serotypes of Listeria monocytogenes, an important foodborne pathogen, in gallbladder samples from cattle and sheep.

Materials and Methods: Three hundred samples were collected and screened for the presence of L. monocytogenes. The identification of the isolates was confirmed by API-Listeria system and by the presence of hemolysin (hyl) gene. The isolates were subjected to polymerase chain reaction-based serotype identification with d1 (division 1), d2 (division 2), glt, mama (mismatch amplification mutation assay), and flaA (flagellin protein) genes.

Results: A total of 8 (2.7\%) L. monocytogenes were recovered from $6(4.0 \%)$ samples of sheep and 2 (1.3\%) samples of cattle. All isolates showed positive results with Hly primers. Four isolates carried $d 1$ gene, did not possess glt gene and harbored mama gene. The serotypes of these isolates were identified as $4 \mathrm{a}$ or $4 \mathrm{c}$. The other 4 isolates carried $d 2$ gene, 3 of them were positive with the FlaA primers, and hence, determined to be a 1/2a or 3a serotype, and 1 isolate was determined to be $1 / 2 \mathrm{c}$ or $3 \mathrm{c}$ serotype.
\end{abstract}

Conclusion: This study concluded that the presence of 1/2a serotype in gallbladder samples indicates public health risk through cross-contamination of meat at slaughterhouses.

Keywords: cattle, gallbladder, Listeria monocytogenes, molecular detection, sheep.

\section{Introduction}

Listeria monocytogenes is a Gram-positive, facultative, intracellular bacterial pathogen that causes morbidity and mortality in human and livestock [1]. It is a significant foodborne pathogen due to its widespread distribution in nature [2]. Gahan and Hill [3] have already described the isolation of L. monocytogenes from the gallbladder in humans. The species has the important feature of virulence as it can colonize in the gallbladder together with extracellular multiplication, which revealed to the presence of an L. monocytogenes-specific gene, termed $b s h$, encoding a bile salt hydrolase [4].

L. monocytogenes strains are serotyped according to variation in the somatic $(\mathrm{O})$ and flagellar $(\mathrm{H})$ antigens [5]. Although more than 13 serotypes of L. monocytogenes have been described [6], only three

Copyright: Al-Ali, et al. Open Access. This article is distributed under the terms of the Creative Commons Attribution 4.0 International License (http://creativecommons.org/licenses/by/4.0/), which permits unrestricted use, distribution, and reproduction in any medium, provided you give appropriate credit to the original author(s) and the source, provide a link to the Creative Commons license, and indicate if changes were made. The Creative Commons Public Domain Dedication waiver (http://creativecommons.org/ publicdomain/zero/1.0/) applies to the data made available in this article, unless otherwise stated. serotypes $(1 / 2 \mathrm{a}, 1 / 2 \mathrm{~b}$, and $4 \mathrm{~b})$ source the vast majority of clinical cases [7]. Numerous molecular subtyping techniques have identified two major phylogenetic divisions within the species. Division I consists of serotypes $1 / 2 b, 3 b, 4 b, 4 d$, and $4 \mathrm{e}$, and Division II consists of serotypes $1 / 2 \mathrm{a}, 1 / 2 \mathrm{c}, 3 \mathrm{a}$, and $3 \mathrm{c}$, and a Division III consisting of less common serotypes $4 \mathrm{a}$ and $4 \mathrm{c}$ have also been identified [8]. Polymerase chain reaction (PCR) has been used for detection of serotype groups of $L$. monocytogenes isolates using specific primers related to Division I/III and Division II genes $[5,9]$.

No information about molecular serotyping of L. monocytogenes derived from animal sources is available in Iraq. Therefore, an increased demand to investigate the dissemination of $L$. monocytogenes serotypes exists, and hence, this study was designed to determine distribution as well as serotype of L. monocytegenes in gallbladders of cattle and sheep.

\section{Materials and Methods}

\section{Ethical approval}

The approval from the Institutional Animal Ethics Committee to carry out this study was not required as no invasive technique was used. 


\section{Sample collection}

A total of 300 bile salt samples were collected from gallbladder of cattle $(n=150)$ and sheep $(n=150)$ from the main slaughterhouse in Najaf province, central Iraq. The specimen collection period was from November 2015 to April 2016. All bile samples were stored at $-20^{\circ} \mathrm{C}$ until analysis. Standard bacterial strain L. monocytogenes 10403 s was obtained from central health laboratory, Baghdad, Iraq.

\section{Isolation and identification of bacterial isolates}

The International Dairy Federation method was used for isolation and identification of Listeria spp. [10]. All samples were incubated at $4^{\circ} \mathrm{C}$ for 1 week and centrifuged (Eppendorf 5417R refrigerate centrifuge, Germany) at $6000 \mathrm{rpm}$ for $20 \mathrm{~min}$. A $1 \mathrm{ml}$ of bile salt pellets added into $9 \mathrm{ml}$ of Listeria enrichment broth (HiMedia, India) and incubated at $30^{\circ} \mathrm{C}$ for $48 \mathrm{~h}$. After that, $0.1 \mathrm{ml}$ of the enrichment broth culture was spread on HiCrome Listeria agar modified (HiMedia, India) and incubated at $37^{\circ} \mathrm{C}$ for 24-48 h. The isolates were identified to the level of species according to standard microbiological methods [11] and confirmed by API Listeria test (BioMerieux, France). The colonial morphology and biochemical tests of Listeria isolates were compared with standard L. monocytogenes strain 10403 s.

\section{Molecular detection of serotype groups of isolates by PCR}

L. monocytogenes DNA extraction was done using Genomic DNA Mini Kit (Geneaid, USA). DNA templates were subjected to PCR using one set of primers targeting hly gene and six sets of primers targeting serotypes genes listed in Table-1.

The reaction mixture contained AccuPower ${ }^{\mathrm{TM}}$ PCR PreMix (Bioneer, Korea), which premixed ready-to-use solution containing Tag DNA polymerase, dNTP, $\mathrm{MgCl}_{2}$, and according to Bioneer procedure (Bioneer Corporation, Korea). The mixture was prepared in $0.2 \mathrm{ml}$ Eppendorf tube with $20 \mu \mathrm{l}$ reaction volumes. The PCR was performed with PCR system (GeneAmp PCR system 9700, Applied Biosystem, Singapore) at $95^{\circ} \mathrm{C}$ for $3 \mathrm{~min}$ except with mama gene, $94^{\circ} \mathrm{C}$ for $5 \mathrm{~min}$ for 1 cycle. For the $h l y$ gene, $94^{\circ} \mathrm{C}, 1 \mathrm{~min} ; 60^{\circ} \mathrm{C}, 1 \mathrm{~min} ; 72^{\circ} \mathrm{C}$, $1 \mathrm{~min}$ for a total of 30 cycles, then $72^{\circ} \mathrm{C}$ for $10 \mathrm{~min}$. For $d 1$ and $d 2$ genes, $95^{\circ} \mathrm{C}, 1 \mathrm{~min} ; 60^{\circ} \mathrm{C}, 30 \mathrm{~s} ; 72^{\circ} \mathrm{C}$, $1 \mathrm{~min}$ for a total of 25 cycles, then $72^{\circ} \mathrm{C}$ for $10 \mathrm{~min}$. For glt gene, $95^{\circ} \mathrm{C}, 30 \mathrm{~s} ; 51^{\circ} \mathrm{C}, 30 \mathrm{~s} ; 72^{\circ} \mathrm{C}, 1 \mathrm{~min}$ for a total of 25 cycles, then $72^{\circ} \mathrm{C}$ for $10 \mathrm{~min}$. For fla $\mathrm{A}$ gene, $95^{\circ} \mathrm{C}, 30 \mathrm{~s} ; 54^{\circ} \mathrm{C}, 30 \mathrm{~s} ; 72^{\circ} \mathrm{C}, 1 \mathrm{~min}$ for a total of 30 cycles, then $72^{\circ} \mathrm{C}$ for $10 \mathrm{~min}$. For mama gene, $94^{\circ} \mathrm{C}, 30 \mathrm{~s} ; 48^{\circ} \mathrm{C}, 30 \mathrm{~s} ; 72^{\circ} \mathrm{C}, 1 \mathrm{~min}$ for a total of 32 cycles, then $72^{\circ} \mathrm{C}$ for $10 \mathrm{~min}$. PCR products were separated by electrophoresis in agarose gel containing ethidium bromide $(0.5 \mathrm{mg} / \mathrm{mL})$ and visualized in-gel documentation system (BioDocAnalyze Live, Biometra-biomedizinische Analytic $\mathrm{GmbH}$, Germany).

\section{Results}

Isolation and identification of bacterial isolates

Only $8(2.7 \%)$ of the 300 bile salt samples were found positive for Listeria species. The bacteria were present in $4.0 \%(6 / 150)$ of sheep samples and 1.3\% (2/150) of cattle samples (Table-2). However, the identification of the suspect colonies was confirmed as they appeared as typical Listeria species when they subcultured onto HiChrom Listeria agar plates and incubated at $37^{\circ} \mathrm{C}$ for $48 \mathrm{~h}$. All eight isolates were grown on this medium (typical L. monocytogenes colonies) with a special characteristic of blue colonies with a yellow halo (rhamnose fermenting colonies) ranging from 1.5 to $5 \mathrm{~mm}$ in diameter. All isolates were confirmed as L. monocytogenes using API-Listeria tests. In addition, the confirmation process of the L. monocytogenes isolates was also conducted by PCR assay to detect the presence of specific virulence trait, $h y l$ gene. The isolates were positive with Hly primers (Figure-1). All isolates were obtained separately from November to February.

\section{PCR-based serotype identification}

The isolates were tested with D1 primers than with D2 primers. Only $4(50.0 \%)$ isolates (Lm5, Lm6, $\mathrm{Lm} 7$, and Lm8) yielded amplification products with the D1 primers (Figure-2), and the other $4(50.0 \%)$ isolates (Lm1, Lm2, Lm3, and Lm4) were amplified with D2 primers (Figure-3).

The four D1 positive isolates were further tested using the Glt primer set. Results revealed that all the D1 positive isolates were negative with the Glt primers. However, negative Glt isolates were tested with Mama-PCR primers to differentiate the serotypes.

Table-1: The primers with their sequences and product size (5).

\begin{tabular}{|c|c|c|c|}
\hline $\begin{array}{l}\text { Primer } \\
\text { name }\end{array}$ & & DNA sequence $(5 x-3 x)$ & $\begin{array}{l}\text { Product } \\
\text { size (bp) }\end{array}$ \\
\hline \multirow[t]{2}{*}{$\mathrm{D} 1^{\mathrm{a}}$} & $\mathrm{F}$ & CGATATTTTATCTACTITGTCA & 214 \\
\hline & $\mathrm{R}$ & TTGCTCCAAAGCAGGGCAT & \\
\hline \multirow[t]{2}{*}{$\mathrm{Glt}^{\mathrm{b}}$} & $\mathrm{F}$ & AAAGTGAGTTCTTACGAGATTT & 483 \\
\hline & $\mathrm{R}$ & AATTAGGAAATCGACCTTCT & \\
\hline \multirow[t]{2}{*}{ Mamac } & $\mathrm{F}$ & CAGTTGCAAGCGCTTGGAGT & 286 \\
\hline & $\mathrm{R}$ & GTAAGTCTCCGAGGTTGCAA & \\
\hline \multirow[t]{2}{*}{$\mathrm{D} 2^{\mathrm{a}}$} & $\mathrm{F}$ & GCGGAGAAAGCTATCGCA & 140 \\
\hline & $\mathrm{R}$ & TTGTTCAAACATAGGGCTA & \\
\hline \multirow[t]{2}{*}{ FlaA $^{b}$} & $\mathrm{~F}$ & TTACTAGATCAAACTGCTCC & 538 \\
\hline & $\mathrm{R}$ & AAGAAAAGCCCCTCGTCC & \\
\hline \multirow[t]{2}{*}{ Hlyc } & $\mathrm{F}$ & CGGAGGTTCCGCAAAAGATG & 234 \\
\hline & $\mathrm{R}$ & CCTCCAGAGTGATCGATGTT & \\
\hline
\end{tabular}

$\mathrm{F}=$ Forward primer, $\mathrm{R}=$ Reverse primer, ${ }^{2} \mathrm{2} \%$ agarose gel, ${ }^{b} 1.2 \%$ agarose gel, c1.5\% agarose gel

Table-2: Distribution of $L$. monocytogenes in sheep and cattle.

\begin{tabular}{lccc}
\hline $\begin{array}{l}\text { Type of } \\
\text { animal }\end{array}$ & $\begin{array}{c}\text { Number of } \\
\text { samples }\end{array}$ & $\begin{array}{c}\text { Number of } \\
\text { positive samples }\end{array}$ & Percentage \\
\hline Sheep & 150 & 6 & 4.0 \\
Cattle & 150 & 2 & 1.3 \\
Total & 300 & 8 & 2.7 \\
\hline
\end{tabular}




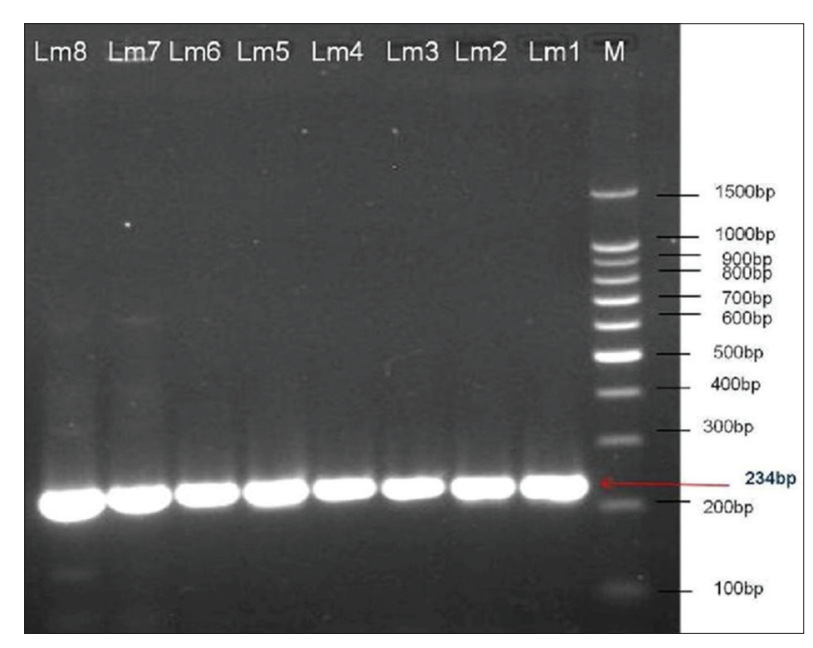

Figure-1: Ethidium bromide-stained agarose gel showing polymerase chain reaction products of Listeria monocytogenes DNA amplified with Hly primers. The electrophoresis performed at 80 volts for $1.25 \mathrm{~h}$. Lane M, molecular-sized marker (100 bp DNA ladder). Lanes Lm1-Lm8 showed amplification of hly gene at 234 bp.

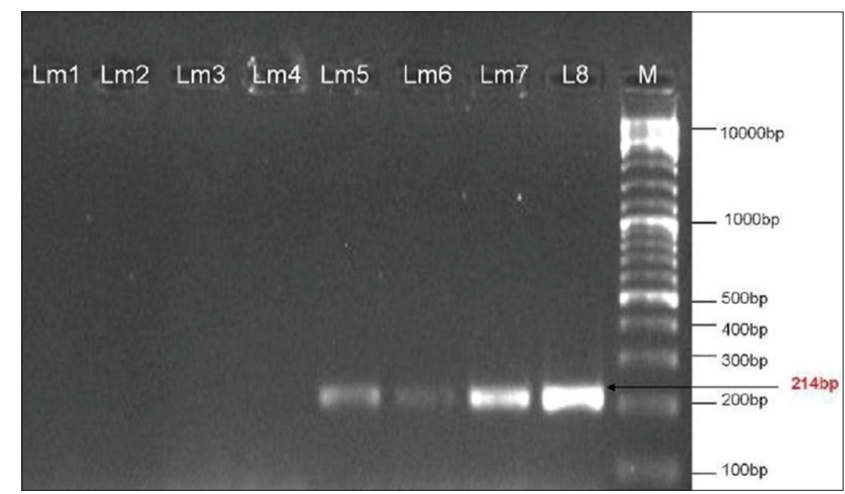

Figure-2: Ethidium bromide-stained agarose gel showing polymerase chain reaction products of Listeria monocytogenes DNA amplified with D1 primers. The electrophoresis performed at 80 volts for $1.25 \mathrm{~h}$. Lane M, molecular-sized marker (100 bp DNA ladder). Lanes Lm4-Lm8 showed amplification of $d 1$ gene at 214 bp.

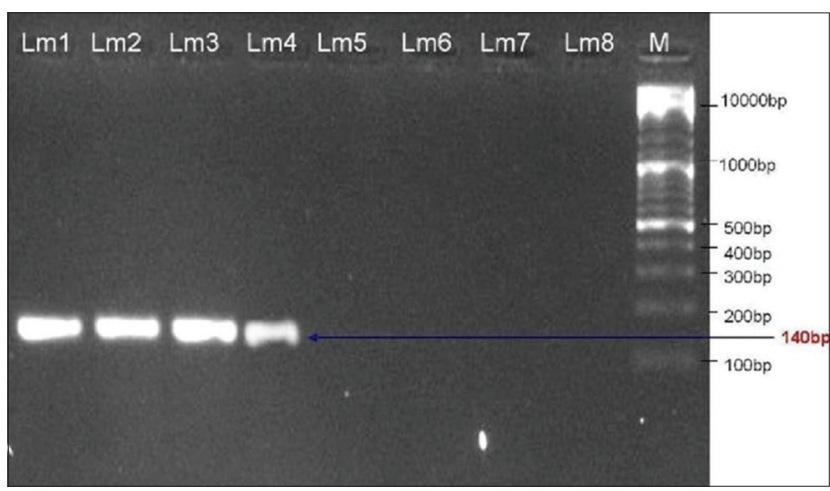

Figure-3: Ethidium bromide-stained agarose gel showing polymerase chain reaction products of Listeria monocytogenes DNA amplified with D2 primers. The electrophoresis performed at 80 volts for $1.25 \mathrm{~h}$. Lane M, molecular-sized marker (100-10000 bp DNA ladder). Lanes Lm1-Lm4 showed amplification of $d 2$ gene at $140 \mathrm{bp}$.

All four isolates gave positive results with Mama primers (Figure-4); therefore, the positive results determined that the serotypes for those isolates were the $4 \mathrm{a}$ or $4 \mathrm{c}$ serotypes. While all D2 positive isolates were further tested using FlaA primer set.

Three $(75.0 \%)$ of the D2 positive isolates ( $\mathrm{Lm} 1$, $\mathrm{Lm} 2$, and Lm3) were positive when tested with the FlaA primers, and therefore, determined to be a $1 / 2 \mathrm{a}$, or 3a serotypes. Whereas, $1(25.0 \%)$ isolate (Lm4) tested negative with FlaA primer set, and therefore, determined to be $1 / 2 \mathrm{c}$ or $3 \mathrm{c}$ (Figure-5).

Overall, serotype distribution showed that 4 isolates were serotype $4 \mathrm{a}$ or $4 \mathrm{c}$ (Lineage III), 3 isolates were serotype $1 / 2 \mathrm{a}$ or $3 \mathrm{a}$ (Lineage II), and only one isolate was a $1 / 2 \mathrm{c}$ or $3 \mathrm{c}$ serotype (Lineage II). The remaining serotypes $(1 / 2 b, 3 b, 4 b, 4 d$, and $4 e)$ were not determined in the present study.

\section{Discussion}

L. monocytogenes is known to cause listeriosis in humans and animals. No information on occurrence and distribution of $L$. monocytogenes in both veterinary and public health sectors in Najaf, Iraq, are found. Results showed that eight L. monocytogenes isolates were recovered from bile salts samples of sheep and cattle. We suggest that the occurrence of Listeria in the gallbladder of sheep and cattle was less frequent. This result was comparable with results of a survey undertaken in Al-Muthanna province, Iraq by Al-Zubaidi [12] who reported that the isolation rates of L. monocytogenes from gallbladder of sheep and human were $20 \%$ and $4 \%$, respectively, but no isolate was recovered from cattle. Marien et al. [13] documented that only one L. monocytogenes isolate was recovered from the gallbladder of a dog in Belgium. No studies other than the above mentioned are available on dissemination of this species in gallbladder of animals. We suggest that the presence of a significant public health hazard is linked to the consumption of meat contaminated with L. monocytogenes as it is generally assumed that raw meat products cannot be free from L. monocytogenes. This may be due to the procedures of evisceration and food processing conducted in the local slaughterhouse of Najaf province (area of the study) that allows a greater chance of contamination. Furthermore, Listeria species are ubiquitous in the environment [14]. People handling food at different levels can also be sources of contamination [15,16]. According to Borch et al. [17], L. monocytogenes transmission to the carcasses does not occur primarily through the animal but is mainly linked to the slaughterhouse environment. Although there are no reports of $L$. monocytogenes infection in the area of this study, and since high fatality rate related to the infection caused by this pathogen, attention should be focused on accurate and early diagnosis of this etiological agent and disease.

In the present demonstration, the isolation rate of L. monocytogenes from gallbladder of sheep was more than that obtained from cattle. Al-Zubaidi [12] found that no isolate was detected in cattle compared 


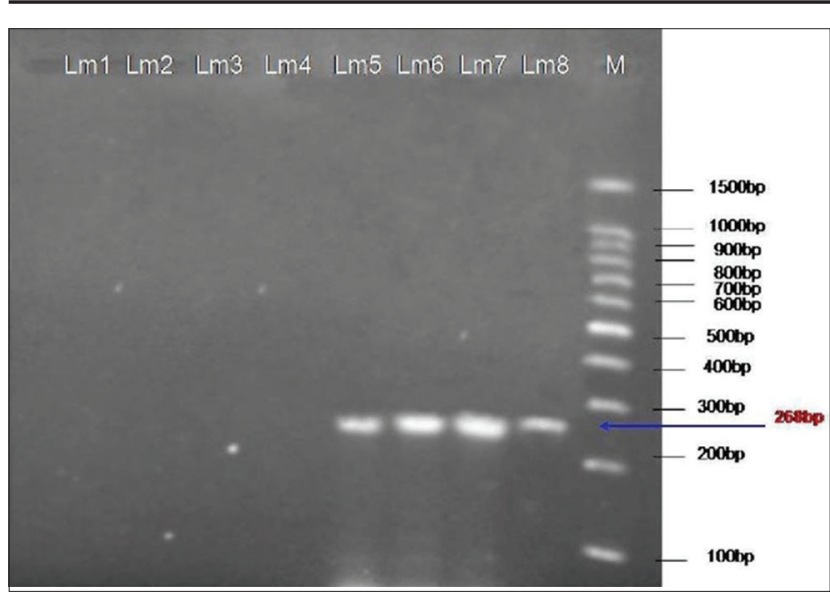

Figure-4: Ethidium bromide-stained agarose gel showing polymerase chain reaction products of Listeria monocytogenes DNA amplified with Mama primers. The electrophoresis performed at 80 volts for $1.25 \mathrm{~h}$. Lane M, molecular-sized marker (100-1500 bp DNA ladder). Lanes Lm5-Lm8 showed amplification of mama gene at 268 bp.

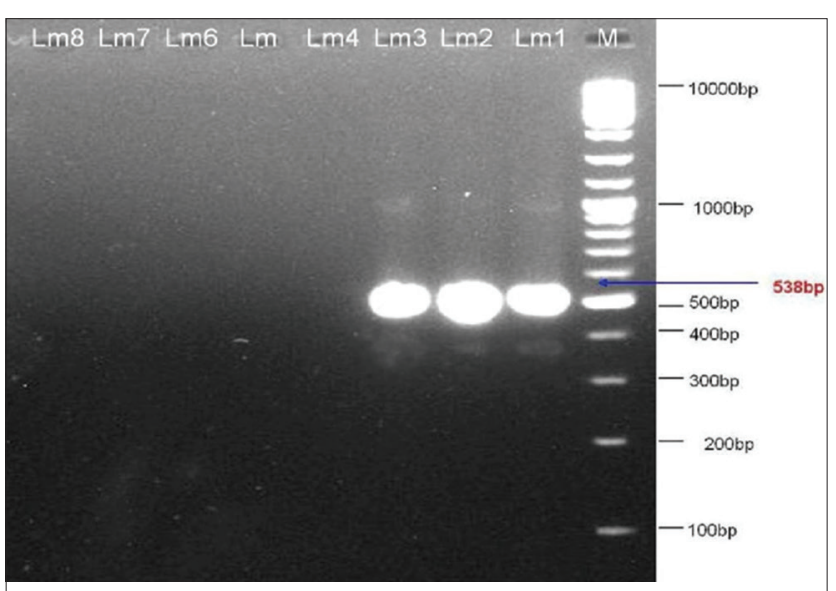

Figure-5: Ethidium bromide-stained agarose gel showing polymerase chain reaction products of Listeria monocytogenes DNA amplified with FlaA primers. The electrophoresis performed at 80 volts for $1.25 \mathrm{~h}$. Lane $\mathrm{M}$, molecular-sized marker (100-10000 bp DNA ladder). Lanes Lm1-Lm3 showed amplification of flaA gene at $538 \mathrm{bp}$.

with sheep (20\%). This may be due to the fact that cows inherently less susceptible to this disease than other animals such as sheep and goats [18] and that the components of bile as cows have a number of additional bile acids comparing to human and sheep, the bile in human and sheep contain mainly cholic acid and genodeoxycholic [19]. Other salts are found in the bile components of cows at important concentrations such as saprocholic, citrolic, and litholic, and this change has importance in sensitivity of cows for infection with L. monocytogenes relatively less than for sheep [20]. The tradition of consuming raw or undercooked meat exacerbates the public health risk associated with L. monocytogenes, as Al-Zubaidi [12] reported the presence of $L$. monocytogenes in raw meat slices, ground meat, and in meat processing environments. In addition, further processing and handling of meat and coating with spices increase the risk of contamination with Listeria species as a final point; we support the hypothesis that gallbladders of cattle and sheep may be representing as a reservoir for human L. monocytogenes infections.

The frequency of $L$. monocytogenes positive gallbladder samples tends to occur during cold months. Similar results were reported by Bonardi et al. [21].

Specific primers were used (for hly gene) to confirm detection of L. monocytogenes isolates; the gene encoded important virulence factor (Listeriolysin $\mathrm{O}$ ), a pore-forming exotoxin essential for invasion into the host cells and lysis of the phagosomes and that responsible for intracellular replication of L. monocytogenes [22]. All isolates were carried the hly gene, present result consistent with Jinneman and Hill [23]. The ability of Listeria species to produce hemolysis is closely correlated with their pathogenicity [1].

Commonly used strategies to serotypes L. monocytogenes strains are based on conventional and PCR methods [24,25]. However, the main objective of this study was to determine the isolates serotypes (by PCR). This study will provide baseline information and templates for practical epidemiological applications.

The amplified products for D1 (50.0\%) and D2 $(50.0 \%)$ were detected in the isolates. Borucki and Call [5] reported that D1 and D2 primers differentiated serotypes $1 / 2 b, 3 b$, and serotype 4 strains from serotypes $1 / 2 \mathrm{a}, 1 / 2 \mathrm{c}, 3 \mathrm{a}$, and $3 \mathrm{c}$. The four isolates identified as belonging in Division I/III (D1) were subtyped using primers designed to differentiate serotypes 4 and $1 / 2 b / 3 b$. These primers called Glt were designed from a $1 / 2$ b serotype specific region flanking the glt $A-B$ cassette described by Lei et al. [26]. However, the four isolates did not give the expected PCR product size with Glt primers. The isolates negative to Glt were subjected to PCR using Mama primers. Isolates tested positive with these primers were identified as $4 \mathrm{a}$ or $4 \mathrm{c}$.

All the four isolates gave positive results with Mama specific primers. The present study revealed that serotype $4 \mathrm{~b}$ was not detected since the four D1 positive isolates were also positive with Mama specific primers. However, serotype $4 b$ has been found to be the main serotype associated with human listeriosis [27].

The four isolates identified as belonging to Division II (D2) were serotyped using primers designed from the flaA gene, which encodes the L. monocytogenes flagellin protein [28]. Isolates that tested positive with the FlaA primers were considered as serotype $1 / 2 \mathrm{a}$ or $3 \mathrm{a}$, while isolates tested negative were considered as serotype $1 / 2 \mathrm{c}$ or $3 \mathrm{c}$ [5]. Through the study, serotypes distribution showed that out of 4 isolates, three were belonged to serotypes $1 / 2 \mathrm{a}$ or $3 \mathrm{a}$, while 1 isolate belonged to serotype $1 / 2 \mathrm{c}$ or $3 \mathrm{c}$.

Most studies found serotypes $1 / 2 \mathrm{a}$ and $1 / 2 \mathrm{~b}$ as the most common serotypes in food [29,30], a finding that is also supported in studies by Gilot et al. [31]. 
Wallace et al. [30] found serotype $1 / 2$ a in $90 \%$ of all the L. monocytogenes isolates tested in food samples. One ambition of present study was to identify the presence of serotype $1 / 2 \mathrm{a}$ or $3 \mathrm{a}$ which is the number one among the L. monocytogenes serotypes associated with human listeriosis [27]. However, this serotype was positively detected. This serotype has also been detected in foodstuffs in the previous study [27]. It was observed that $L$. monocytogenes serotypes $1 / 2 \mathrm{a}$, $1 / 2 b$, and $4 b$ are responsible for $98 \%$ of documented human listeriosis cases [32]. The presence of $1 / 2 \mathrm{a}$ serotype in bile salt samples indicated a risk factor to infect the human through cross-contamination of meat in slaughterhouse, and this was consistent with Sjoman [33] who observed that serotype $1 / 2 \mathrm{a}$ was the most common for human infections during 1990-2001 in Finland.

\section{Conclusion}

We concluded that gallbladders of cattle and sheep may be representing a pool for human L. monocytogenes infection and the presence of $1 / 2 \mathrm{a}$ serotype indicates that there is a risk for human infection through cross-contamination of meat in slaughterhouses in the location of the study.

\section{Authors' Contributions}

We declare that this work was done by the authors named in this article and all liabilities pertaining to claims relating to the content of this article will be borne by the authors. HJA and MAA are main supervisors of the study, organized the data, and responsible for interpretation of the results. SAA and $\mathrm{ZJH}$ collected the samples from the slaughterhouses. AHA and AMA were responsible for the laboratory data analysis. All authors read and approved the final manuscript.

\section{Acknowledgments}

This work was funded by the Iraqi Ministry of Higher Education and Scientific Research. The authors are thankful to deanship of Kufa University for providing all the requirements necessary for this study and for the facilities and internet service required for drafting this manuscript. No fund was received for this study.

\section{Competing Interests}

The authors declare that they have no competing interests.

\section{References}

1. Vazquez-Boland, J.A., Kuhn, M., Berche, P., Chakraborty, T., Domínguez-Bernal, G., Goebel, W., González-Zorn, B., Wehland, J. and Kreft, J. (2001) Listeria pathogenesis and molecular virulence determinants. Clin. Microbiol. Rev., 14: 584-640.

2. Liu, D., Lawrence, M., Austin, F.W. and Ainsworth, A.J. (2005) Comparative assessment of acid, alkali and salt tolerance in Listeria monocytogenes virulent and avirulent strains. FEMS Microbiol. Lett., 243: 373-378.

3. Gahan, C.G., and Hill, C. (2005) Gastrointestinal phase of Listeria monocytogenes infection. J. Appl. Microbiol.,
98: $1345-1353$.

4. Glaser, P., Frangeul, L., Buchrieser, C., Rusniok, C., Amend, A., Baquero, F., Berche, P., Bloecker, H., Brandt, P. and Chakraborty, T. (2001) Comparative genomics of Listeria species. Science, 294: 849-852.

5. Borucki, M.K. and Call, D.R. (2003) Listeria monocytogenes serotypes identification by PCR. J. Clin. Microbiol., 41: 5537-5540

6. Borucki, M.K., Gay, C.C., Reynolds, J., McElwain, K.L., Kim, S.H., Call, D.R. and Knowles, D.P. (2005) Genetic diversity of Listeria monocytogenes strains from a high-prevalence dairy farm. Appl. Environ. Microbiol., 71: 5893-5899.

7. Tappero, J.W., Schuchat, A., Deaver, K.A., Mascola, L. and Wenger, J.D. (1995) Reduction in the incidence of human listeriosis in the United States. Effectiveness of prevention efforts? JAMA, 273: 1118-1122.

8. Aarts, H.J., Hakemulder, L.E. and Van Hoef, A.M. (1999) Genomic typing of Listeria monocytogenes strains by automated laser fluorescence analysis of amplified fragment length polymorphism fingerprint patterns. Int. J. Food Microbiol., 49: 95-102.

9. Al-Shukri, M.S. (2010) Molecular and Genetic Study of Some Virulence Factors of Listeria monocytogenes. Ph.D. Thesis. Babylon University.

10. OIE Terrestrial Manual. (2012) Listeria monocytogenes. The Manual of Diagnostic Tests and Vaccines for Terrestrial Animals (Terrestrial manual). Ch. 2.9.7. $7^{\text {th }}$ ed. OIE Terrestrial Manual, Paris, France.

11. Barrow, G.I. and Feltham, R.K.A. (2003) Cowan and Steels' Manual for Identification of Medical Bacteria. $3^{\text {rd }}$ ed. Cambridge University Press, United Kingdom.

12. Al-Zubaidi, K.I. (2006) Natural and Experimental Study for the Localization of the Listeria monocytogenes in some of the Internal and its Role in the Spread of the Disease. M.Sc Thesis. Baghdad University.

13. Marien, M., Decostere, A., Werbrouck, H. and Van Coillie, E. (2007) Department of Pathology, Bacteriology and Avian Diseases, Faculty of Veterinary Medicine. Ghent University, Salisburylaan, Merelbeke, Belgium. p133, B-9820.

14. Vitas, A.I. and Garcia-Jalon, V.A. (2004) Occurrence of Listeria monocytogenes in fresh and processed foods in Navarra (Spain). Int. Food Microbiol., 90: 349-356.

15. Lundén, J., Autio, T., Markkula, A., Hellström, S. and Korkeala, H. (2003) Adaptive and cross-adaptive responses of persistent and non-persistent Listeria monocytogenes strains to disinfectants. Int. J. Food Microbiol., 82: 265-272.

16. Lundén, J., Autio, T., Sjöberg, A.M. and Korkeala, H. (2003) Ecology of persistent and non-persistent Listeria monocytogenes strains in meat and poultry processing plants. J. Food Protect., 66: 2062-2069.

17. Borch, E., Nesbakken, T. and Christensen, H. (1996) Hazard identification in swine slaughter with respect to foodborne bacteria. Int. J. Food Microbiol., 30: 9-25.

18. Al-Dughaym, A.M., Elmula, A.F., Mohamed, G.E., Hegazy, A.A., Radwan, Y.A., Housawi, F.M.T. and Gameel, AA. (2001) First report of an outbreak of ovine septicaemic listeriosis in Saudi Arabia. Rev. Sci. Tech. Int. Epiz, 20: 777-783.

19. Wiggins, H.S. and Woothen, D.P. (1958) Studies in bile acids. Conjugated bile salts of certain primates. Biochem J., 70: 439.

20. Snyth, J.D. (1962) Lysis of Echinococcus granulosus by surfaces active agent in bile and role of this phenomenon in determining host specificity in helminthes. Proc. R. Soc. B., 156: 553-572.

21. Bonardi, L.M., Groppi, F. and Mainardi, H.S. (2002) High specific activity: Radioactivity tracers a powerful tool for studying very low level and long-term exposure to different chemical forms of both essential and toxic elements. Microchem. J., 73: 153-166. 
22. Decatur, A. and Portnoy, D.A. (2000) A PEST-like sequence in listeriolysin $\mathrm{O}$ essential for Listeria monocytogenes pathogenicity. Science, 290: 992-995.

23. Jinneman, K.C. and Hill, W.E. (2001) Listeria monocytogenes lineage group classification by MAMA-PCR of the listeriolysin gene. Curr. Microbiol., 43: 129-133.

24. Graves, L.M., Swaminathan, B. and Hunter, SB. (1999) Subtyping Listeria monocytogenes. In: Ryser, E.T., Marth, E.H., editors. Listeria, Listeriosis and Food Safety. Marcel Dekker Incorporation, New York. p279-298.

25. Gasanov, U., Hughes, D. and Hansbro, P.M. (2005) Methods for the isolation and identification of Listeria spp. and Listeria monocytogenes: A review. FEMS Microbiol. Rev., 29: 851-875.

26. Lei, X.H., Fiedler, F., Lan, Z. and Kathariou, S. (2001) A novel serotype specific gene cassette $(g l t A-g l t B)$ is required for expression of teichoic acid associated surface antigens in Listeria monocytogenes of serotype 4b. J. Bacteriol., 183: 1133-1139.

27. Zhang, Y., Yeh, E., Hall, G., Cripe, J. and Bhagwat, A.A. (2007) Characterization of Listeria monocytogenes isolated from retail foods. Int. Food Microbiol., 113: 47-53.

28. Dons, L., Rasmussen, O.F. and Olsen, J.E. (1992) Cloning and characterization of a gene encoding flagellin of Listeria monocytogenes. Mol. Microbiol., 6: 2919-2929.

29. Aarnisalo, K., Autio, T., Sjoberg, A., Lunden, J., Korkeala, H. and Suihko, M. (2003) Typing of Listeria monocytogenes isolates originating from the food processing industry with automated ribotyping and pulsed-field gel electrophoresis. J. Food Protect., 66: 249-255.

30. Wallace, F.M., Call, J.E., Porto, A.C.S., Cocoma, G.J., ERRC Special Projects Team, and Luchansky, J.B. (2003) Recovery rate of Listeria monocytogenes from commercially prepared frankfurters during extended refrigerated storage. Food Protect., 66: 584-591.

31. Gilot, P., Genicot, A. and Andre, P. (1996) Serotyping and esterase typing for analysis of Listeria monocytogenes populations recovered from foodstuffs and from human patients with listeriosis in Belgium. Clin. Microbiol., 34: 1007-1010.

32. Gombas, D.E., Chen, H.Y., Clavero, C.S. and Scott, V.N. (2003) Survey of Listeria monocytogenes in ready-to-eat foods. J. Food. Prot., 66: 559-569.

33. Sjoman, M. (2010) The Use of Serotyping and PFGE-Typing of Listeria monocytogenes in Food Processing Contamination Studies and Human Foodborne Infections. Department of Food Hygiene and Environmental Health Faculty of Veterinary Medicine University of Helsinki, Finland. 